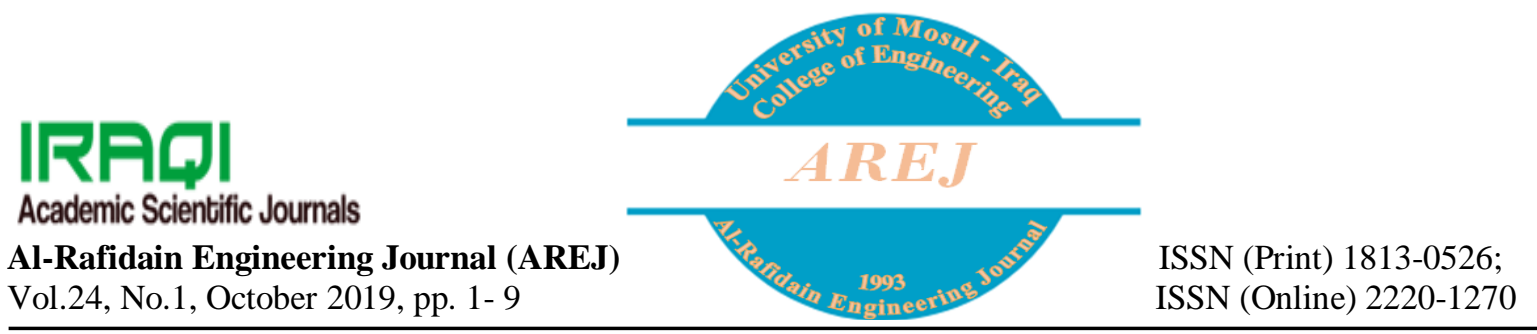

\title{
Laboratory Study of Flow Characteristics Through three Baffle - Sluice Gates.
}

\author{
Duaha A.Al-mallah* \\ Assist. Lecturer \\ Dauha.ali11@umosul.edu.iq \\ Hana A.Hayawi** \\ Assistant Prof. \\ hanahayawi55@umosul.edu.iq \\ *,** Departement of water resources Engineering, University of Mosul
}

Received: 2018-10-22

Accepted: 2019-1-24

\begin{abstract}
The main objective of this study is to investigate the experimentally the coefficient of discharge for three baffle sluice gates and compared with single gate. The channel slope was changed tow times $(0,0.0075)$. For this purpose three baffle sluice gates were made from fibber class with $(1 \mathrm{~cm})$ thick, $(30 \mathrm{~cm})$ wide and $(15,25,30) \mathrm{cm}$ height for first, second and third gate respectively. The three gates have been sharp edge from the top and bottom with $2 \mathrm{~mm}$ thick. The distance between the three parallel baffle gates were changed three times $(2,3.5,5) \mathrm{cm}$. The analysis of results showed that discharge coefficient Cd in horizontal channel is larger than its value in inclined channel with direction of flow and the change in space between gates didn't cause an important difference between values of discharge coefficient $C d$. The values of $C d$ were between $(0.561-0.736)$ for horizontal channel and three gates, while when the channel inclined the values of Cd were between (0.523-0.662) for three gates.
\end{abstract}

\section{Keywords:}

sluice gate; baffle gate; discharge coefficient; parallel baffle gates; single gate.

https://rengj.mosuljournals.com

Email: alrafidain_engjournal@umosul.edu.iq

\section{INTRODUCTION}

Gates are widely used in open channel flow or in irrigation networks as water regulator, flow measurement devices, used for either water delivery or as a check structure. The sluice gate is one of the most common device. Depending to the tail water depth value and gate opening the flow conditions through a vertical Sluicegate can be classified as (Bijankhan et al., 2017).

1- Free flow condition; which occurs when the tail water level is equal or less than the gate opening and the water surface is smooth (Fig. 1-a) (swamee 1992).

2- Submerged flow condition (Fig. 1b) (swamee 1992); which occurs when the tail water level is above the gate opening and the water surface become rough.

The flow characteristics upstream and downstream of baffle sluice gates were studied experimentally by many authors. Sluice gate used as discharge measurement structure was found, by Rajartnam (1977). Ferro's (2000) suggested the first dimensional analysis of a sluice gate flow for free flow condition.

Ansar and Ferro (2001) developed the proposed method to submerged flow condition. A set of modules was originally developed by (Mishra .et al.1990). The module is basically a $(100 \mathrm{~cm})$ long and $(10 \mathrm{~cm})$ wide rectangular channel containing three vertical baffle sluice gates.

A types of flow equations has been approached by theoretical and empirical formulas and by graphical approaches. Swamee(1992) presented two formulas for determining free and submerged discharge coefficients based on the head-discharge curves of (Henry's1950).Babu ,M. et al.,(1996) tested the strength of the design 
proposed by (Mishra et al.,1990) but with a different module dimension. Lin, et al., (2002) presents a theoretical formula and some experimental graphs to determine maximum allowable tail water depth for free flow (or minimum allowable tail water depth for submerged flow). The effect of lower gate edge on water surface profile has been studied in rectangular flume by (Mohammed \& Khaleel, 2013). The discharge coefficient for the free flow through three baffle sluice gates in horizontal and inclined channel was investigated in this study.

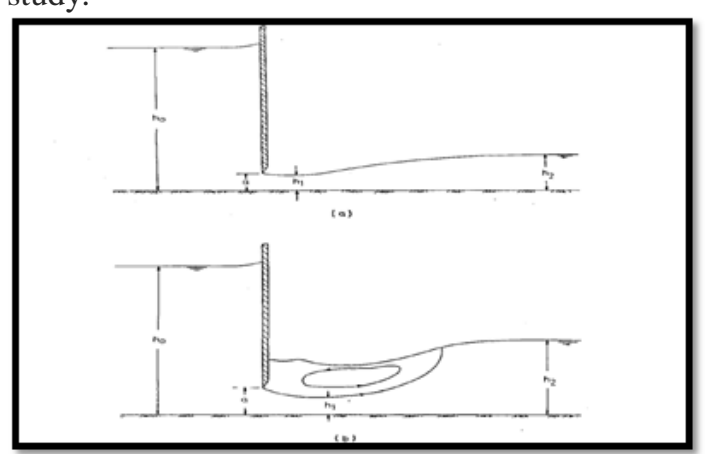

Figer. 1. Type of flow: (a) Free Flow; and (b) Submerged Flow

\section{THE THEORETICAL BASES}

A definition sketch for the different water levels flow through and over three baffle sluice gates, is shown in Fig.(2).

The total discharge through three baffle sluice gates was calculated from equation.

$$
Q_{t h e}=Q_{u}+Q_{d} \quad \ldots 1
$$$$
\text { where: }
$$

$Q_{d}$ : discharge through the opening below the active gate $\left(\mathrm{L}^{3} / \mathrm{T}\right)$.

$Q_{u}$ : discharge over the active gate when the elevation of water increase above the top edge of active gate $\left(\mathrm{L}^{3} / \mathrm{T}\right)$.

$Q_{\text {the }}$ : total theoretical discharge through the active baffle sluice gate $\left(\mathrm{L}^{3} / \mathrm{T}\right)$.

$$
\begin{gathered}
Q_{u}=\frac{2}{3} B \sqrt{2 g} h^{1.5} \quad \ldots 2 \\
Q_{d}=B a \sqrt{2 g H_{1}} \quad \ldots 3 \\
\text { where: }
\end{gathered}
$$

$g$ : acceleration due to gravity $\left(\mathrm{L} / \mathrm{T}^{2}\right)$.

$a$ : gate opening (L).

$B$ : the width of the channel(L).

$h$ : the head over top edge of active gate(L).

$L$ : is the length of the active gate.

$$
\begin{aligned}
& H_{1}: \text { the total head }(\mathrm{m}) ; H_{l}=a+L+h \\
& Q_{\text {act }}=C_{d} Q_{\text {the }} \quad \ldots 4
\end{aligned}
$$$$
\text { where: }
$$

$Q_{\text {act }}:$ the total actual discharge through the standard rectangular weir $\left(\mathrm{m}^{3} / \mathrm{sec}\right)$.

$C d$ : the coefficient of discharge for the baffle sluice gate.

For flow through a baffle sluice gate, the coefficient of discharge $\mathrm{Cd}$ can be expressed by the following functional relationship:

$\mathrm{Cd}=\mathrm{f}\left(\mathrm{L}, \mathrm{a}, \mathrm{e}, \mathrm{B}, \mathrm{H} 1, \mathrm{H} 2, \mathrm{H} 3, \mathrm{H} 4, \mathrm{~S}, \mathrm{~g}, \mu, \rho, Q_{\text {act }} \quad\right.$ ) $\quad \ldots .5$ e: the distance between gates(L).S: slop of the channel. : head of the water before first gate(L). : the head of water before second gate(L). : the head of water before third gate $(\mathrm{L}) . \rho=$ density of water $\left(M L^{-3}\right), \mu$ : dynamic viscosity $\left(M L^{-1} T^{-1}\right)$.

Based on eq .5 and using dimensional analysis (Buckingham $\pi$ Theorem) shows the following:

$C_{d}=$

$f\left(\frac{B}{H_{1}}, \frac{L}{H_{1}}, \frac{a}{H_{1}}, \frac{e}{H_{1}}, \frac{H_{2}}{H_{1}}, \frac{H_{3}}{H_{1}}, \frac{H_{4}}{H_{1}}, S, \frac{\mu H_{1}}{\rho \text { Qact }}, \frac{g H_{1}^{5}}{Q_{\text {aat }}^{2}}\right)$ ...6

number But $\frac{\mu H_{1}}{\rho \text { Qact }}=\frac{1}{R e}$, Where Re is Reynolds

And $\frac{g H_{1}^{5}}{Q_{\text {act }}^{2}}=\frac{1}{F^{2}}$ Where $\mathrm{Fr}$ is froud number

Cc: is the contraction coefficient it found by dividing $\left(\frac{H_{2}}{H_{I}}, \frac{H_{3}}{H_{I}}, \frac{H_{4}}{H_{1}}\right) \div \frac{a}{H_{I}}$

Eq. (6) can be written as

$$
C_{d}=f\left(\frac{B}{H_{1}}, \frac{L}{H_{1}}, \frac{a}{H_{1}}, \frac{e}{H_{1}}, C_{C}, S, \frac{1}{F_{r}}, \frac{1}{R e}\right)
$$

The effected of Reynolds number was negligible. (Negm et. al., 2002).

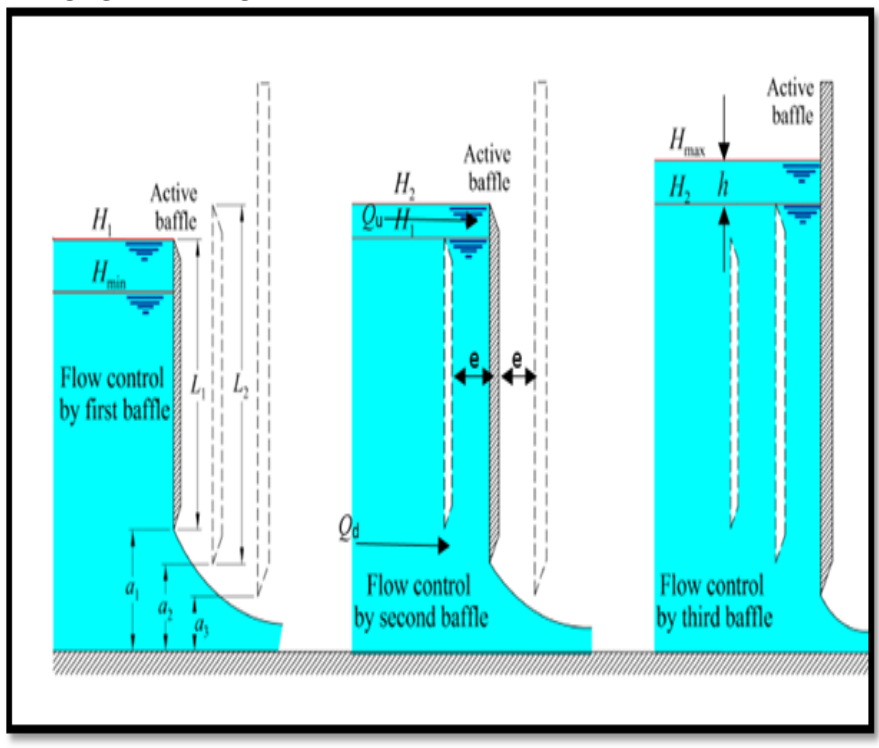

Fig. 2. Flow conditions for each flow controlling baffle

\section{THE PROPOSED METHODOLOGY}


The experiments were conducted in the Hydraulic Laboratory of Dams and water Resources Engineering Department, University of Mosul, Iraq.

All the experiments were carried out in laboratory channel of $(10 \mathrm{~m})$ length, with rectangular cross section $(0.3 \mathrm{~m})$ wide and $(0.45 \mathrm{~m})$ height, channel walls were made of glass, and the bed consisted of stainless-steel plates. The walls of channel were of toughened glass with number of perplex panels united. A pair of a change able instrument rails were fitted on the top of the channel sides through the working length of the channel two movable carriages equipped with point gage were mounted on the rails fig. (3) Shows the laboratory channel used in this study. Each gates was made from fibber class plate $(1 \mathrm{~cm})$ thickness, $(30 \mathrm{~cm})$ width and $(15,25,30 \mathrm{~cm})$ height for first, second and third gate respectively. Gates opening were changed times. The distance between gates changed three times $(2 \mathrm{~cm}, 3.5 \mathrm{~cm}$, $5 \mathrm{~cm})$. Tested model were fixed at $(2 \mathrm{~m})$ downstream of the channel inlet and the discharge were measured with standard full thin plate sharp crested rectangular weir with dimensions $(10 * 30 * 1) \mathrm{cm}$ located at the outlet of the channel, the standard weir manufactured according to the British standard (British standard Institute,1965). The average of three readings of the water surface profiles were recorded for each test, and the discharge passing through the baffle sluice gates

were measured with a standard weir. The water surface level and the head above standard weir were measured with precision point gauge, whose least count was $(0.5 \mathrm{~mm})$. More than 300 experiments were carry out through the work, the experimental program is shown in fig (4).

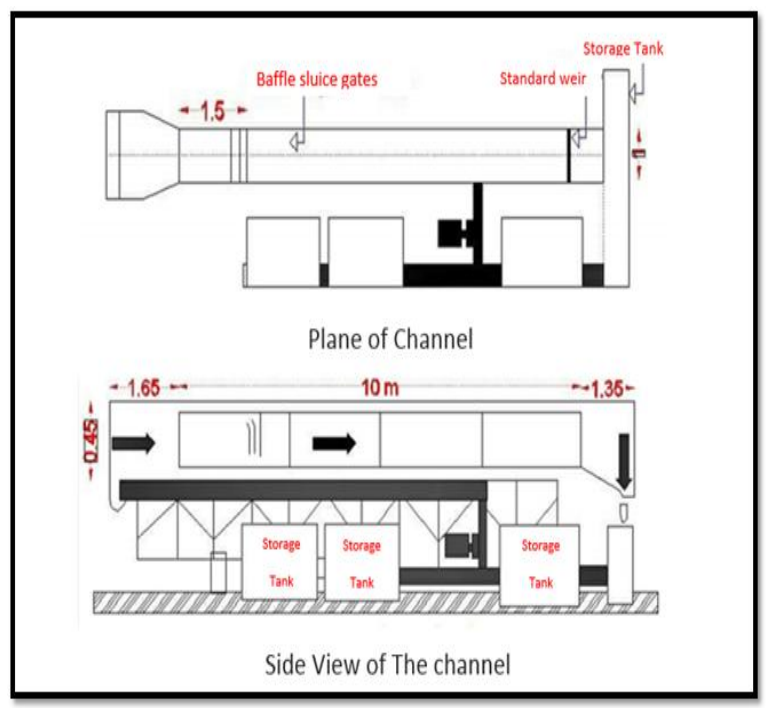

fig.3. Channel Gross Section

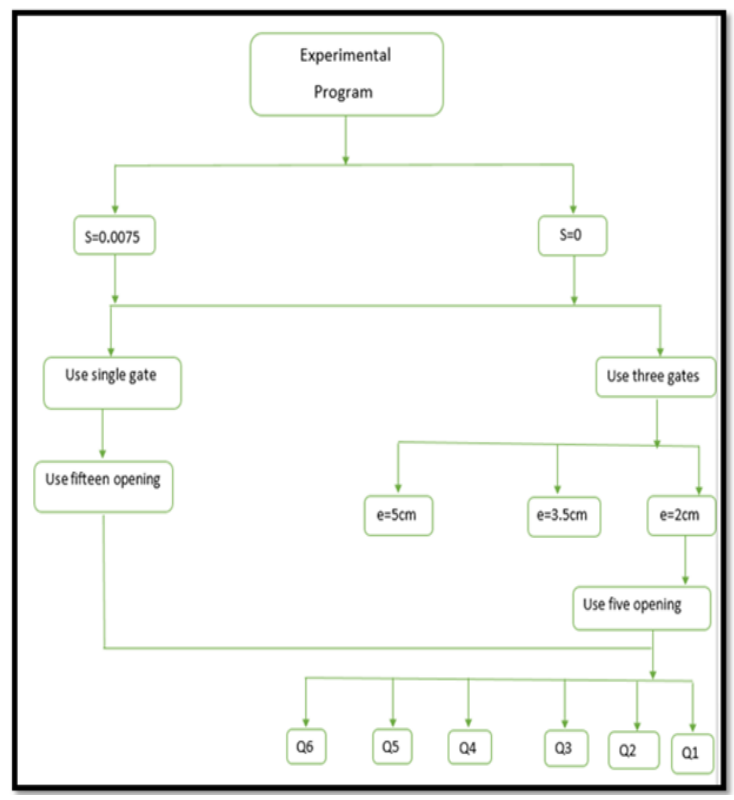

Fig. (4) The Experimental Layout

\section{RESULTS AND DISCUSSIONS}

4.1. Variation of $(\mathrm{Cd})$ with the ratio $\frac{B}{H_{1}}$

The relation between the coefficient of discharge $(\mathrm{Cd})$ and the ratio $\frac{\boldsymbol{B}}{\boldsymbol{H}_{\boldsymbol{1}}}$ for different spaces, different slopes and gate opening $(\mathrm{a} 1=6 \mathrm{~cm}, \mathrm{a} 2=5.5 \mathrm{~cm}, \mathrm{a} 3=5.3 \mathrm{~cm})$ where shown in fig (5\&6).From laboratory measurement it was found that the best relation between $\mathrm{Cd} \& \frac{\boldsymbol{B}}{\boldsymbol{H}_{\boldsymbol{1}}}$ is shown in equation 8 .

$$
C d=c\left(\frac{B}{H_{l}}\right)^{b} \ldots 8
$$

Figures (5\&6) shows that the value of discharge coefficient $\mathrm{Cd}$ decreases with the increase of $\frac{\boldsymbol{B}}{\boldsymbol{H}_{\boldsymbol{1}}}$, and its value increases with the increase distance between baffles. Comparing figure(5) with figure(6) it can be noted that the channel slope has a negative effect on the value of $\mathrm{Cd}$ which shows less values of discharge coefficient $\mathrm{Cd}$ for the same geometric combinations. 


\begin{tabular}{|c|c|c|c|}
\hline \multicolumn{4}{|c|}{ Table (1) shows the parameters of eq. 8} \\
\hline $\mathrm{S}=0$ & $\mathrm{c}$ & b & $R^{2}$ \\
\hline $\mathrm{e}=2 \mathrm{~cm}$ & 0.6194 & -0.013 & 0.9665 \\
\hline $\mathrm{e}=3.5 \mathrm{~cm}$ & 0.6203 & -0.015 & 0.9518 \\
\hline $\mathrm{e}=5 \mathrm{~cm}$ & 0.6212 & -0.015 & 0.9605 \\
\hline Single gate & 0.6247 & -0.021 & 0.9557 \\
\hline$S=0.0075$ & $\mathrm{c}$ & b & $\mathrm{R}^{2}$ \\
\hline $\mathrm{e}=2 \mathrm{~cm}$ & 0.585 & -0.033 & 0.962 \\
\hline $\mathrm{e}=3.5 \mathrm{~cm}$ & 0.5875 & -0.029 & 0.9199 \\
\hline $\mathrm{e}=5 \mathrm{~cm}$ & 0.5897 & -0.027 & 0.9244 \\
\hline Single gate & 0.5965 & -0.041 & 0.9826 \\
\hline
\end{tabular}

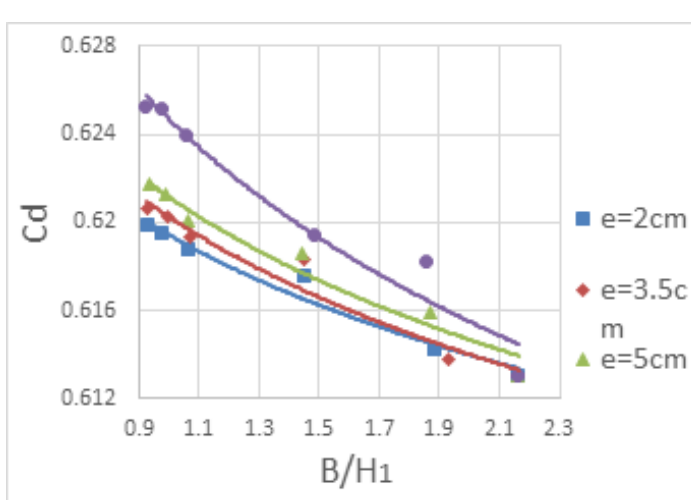

$\mathrm{Fig}(5)$ varition of discharge cofficient $\mathrm{Cd}$ with (B/H1) for different distance between gates $a 1=6 \mathrm{~cm}, a 2=5.5 \mathrm{~cm}, a 3=5.3 \mathrm{~cm}$, for the slope $=0$.

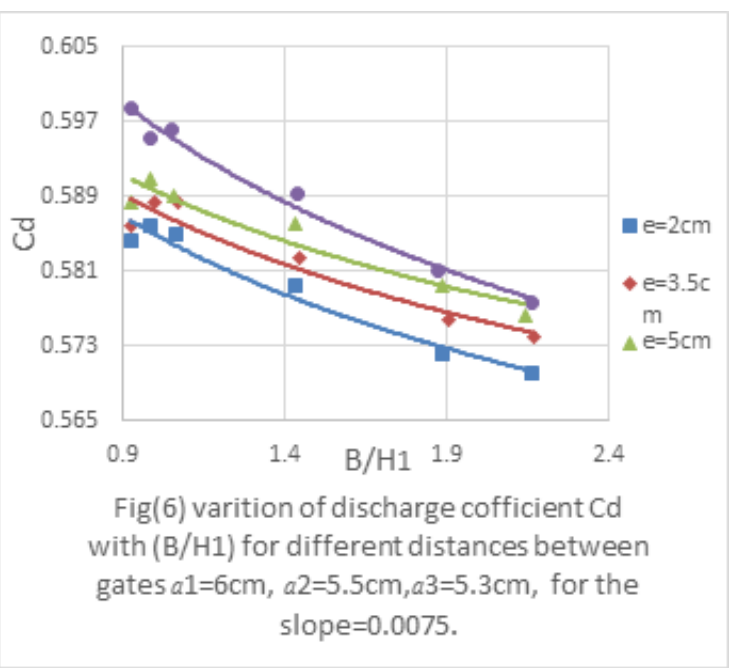

\subsection{Variation of $(\mathrm{Cd})$ with the ratio $\frac{a}{H_{1}}$}

The relation between $\mathrm{Cd}$ and ratio $\frac{\boldsymbol{a}}{\boldsymbol{H}_{1}}$ was drawn in figs $(7,8)$ for different space between gates, for horizontal and inclined channel respectively for constant gate opening $(\mathrm{a} 1=6 \mathrm{~cm}$, $\mathrm{a} 2=5.5 \mathrm{~cm}, \mathrm{a} 3=5.3 \mathrm{~cm}$ ). Equation (9) was found to be the best relation between $\mathrm{Cd} \& \frac{\boldsymbol{a}}{\boldsymbol{H}_{\boldsymbol{i}}}$.

$$
c d=c\left(\frac{a}{H_{1}}\right)^{b} \ldots 9
$$


Duaha A.Al-mallah : Laboratory Study of Flow Characteristics Through .......

\begin{tabular}{|c|c|c|c|}
\hline $\mathrm{e}=2 \mathrm{~cm}$ & 0.608 & -0.011 & 0.9498 \\
\hline $\mathrm{e}=3.5 \mathrm{~cm}$ & 0.6071 & -0.013 & 0.9331 \\
\hline $\mathrm{e}=5 \mathrm{~cm}$ & 0.6075 & -0.013 & 0.943 \\
\hline Single gate & 0.6039 & -0.021 & 0.9557 \\
\hline $\mathrm{S}=0.0075$ & & $\mathrm{~b}$ & $\mathrm{R}^{2}$ \\
\hline $\mathrm{e}=2 \mathrm{~cm}$ & 0.5573 & -0.029 & 0.956 \\
\hline $\mathrm{e}=3.5 \mathrm{~cm}$ & 0.5628 & -0.026 & 0.9176 \\
\hline $\mathrm{e}=5 \mathrm{~cm}$ & 0.5664 & -0.024 & 0.9091 \\
\hline Single gate & 0.5593 & -0.041 & 0.9826 \\
\hline
\end{tabular}

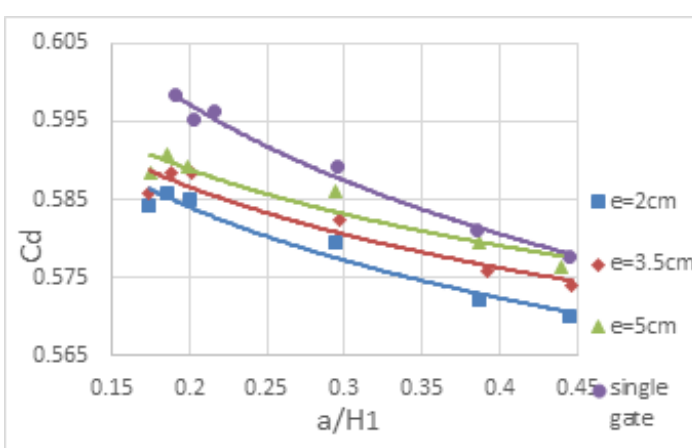

$\mathrm{Fig}(8)$ varition of cofficient of discharge $\mathrm{Cd}$ with $(\mathrm{a} / \mathrm{H} 1)$ for different distance between gates $a_{1}=6 \mathrm{~cm}, a_{2}=5.5 \mathrm{~cm}$, $a_{3}=5.3 \mathrm{~cm}$, for the slope $=0.0075$.

\subsection{Variation of $(\mathrm{Cd})$ with the ratio $\frac{e}{H_{1}}$}

The relation between $\mathrm{Cd}$ and the ratio $\frac{\boldsymbol{e}}{\boldsymbol{H}_{1}}$ space between gates and different slopes for constant gate opening $(\mathrm{a} 1=6 \mathrm{~cm}, \mathrm{a} 2=5.5 \mathrm{~cm}$, $\mathrm{a} 3=5.3 \mathrm{~cm})$. It found that the best relation between $\mathrm{Cd} \& \frac{\boldsymbol{e}}{\boldsymbol{H}_{\mathbf{1}}}$ is shown in equation 10 .

$$
c d=c\left(\frac{e}{H_{l}}\right)^{b} \ldots 10
$$

figures $(7 \& 8)$ shows that the value of discharge coefficient $\mathrm{Cd}$ decreases with the increase of $\frac{\boldsymbol{a}}{\boldsymbol{H}_{1}}$, and its value increases with the increase distance between baffles. Comparing figure(7) with figure(8) it can be noted that the channel slope has a negative effect on the value of $\mathrm{Cd}$ which shows less values of discharge coefficient $\mathrm{Cd}$ for the same geometric combinations.

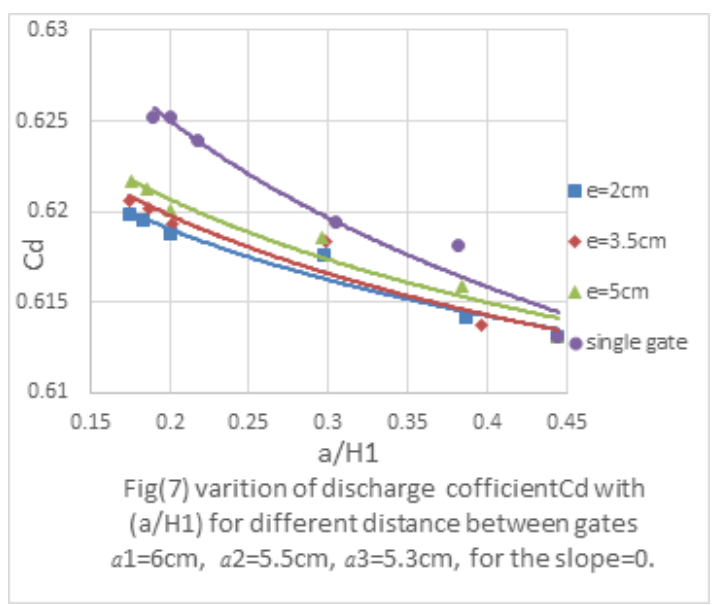

\begin{tabular}{|c|c|c|c|}
\hline \multicolumn{4}{|c|}{ Table (3) shows the parameters of eq. 10} \\
\hline$S=0$ & $\mathrm{c}$ & $\mathrm{b}$ & $R^{2}$ \\
\hline $\mathrm{e}=2 \mathrm{~cm}$ & 0.5986 & -0.013 & 0.9665 \\
\hline $\mathrm{e}=3.5 \mathrm{~cm}$ & 0.6013 & -0.015 & 0.9518 \\
\hline $\mathrm{e}=5 \mathrm{~cm}$ & 0.6052 & -0.015 & 0.979 \\
\hline $\mathrm{S}=0.0075$ & & $\mathrm{~b}$ & $\mathrm{R}^{2}$ \\
\hline $\mathrm{e}=2 \mathrm{~cm}$ & 0.5356 & -0.033 & 0.962 \\
\hline $\mathrm{e}=3.5 \mathrm{~cm}$ & 0.5524 & -0.029 & 0.9199 \\
\hline $\mathrm{e}=5 \mathrm{~cm}$ & 0.5618 & -0.027 & 0.9244 \\
\hline
\end{tabular}


Figures $(9 \& 10)$ shows that the value of discharge coefficient Cd decreases with the increase of $\frac{\boldsymbol{e}}{\boldsymbol{H}_{\boldsymbol{1}}}$, and its value increases with the increase distance between baffles. Comparing figure(9) with figure(10) it can be noted that the channel slope has a negative effect on the value of $\mathrm{Cd}$ which shows less values of discharge coefficient $\mathrm{Cd}$ for the same geometric combinations.
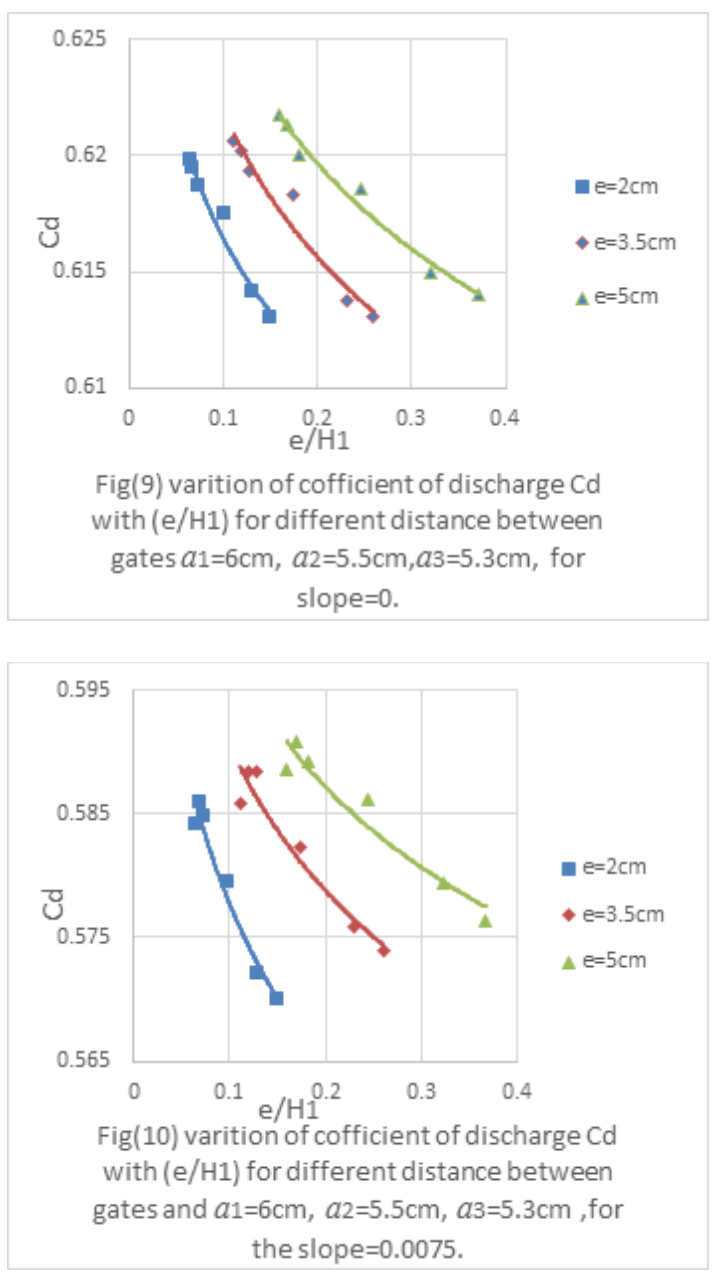

\subsection{Variation of $(\mathrm{Cd})$ with the ratio}

\section{$\frac{1}{\text { Fr }^{2}}$}

The relation between $\mathrm{Cd}$ and the ratio $\left(1 / \mathrm{Fr}^{2}\right)$ is drawn in figs $(11,12)$ for different space between gates and different slop. Equation (11) was found to be the best relation between $\mathrm{Cd}$ $\& \frac{1}{r^{2}}$.

$$
C d=c\left(\frac{1}{\left.r^{2}\right)^{b}}\right)^{b}
$$

Table (4) shows the value of the parameters of eq.11

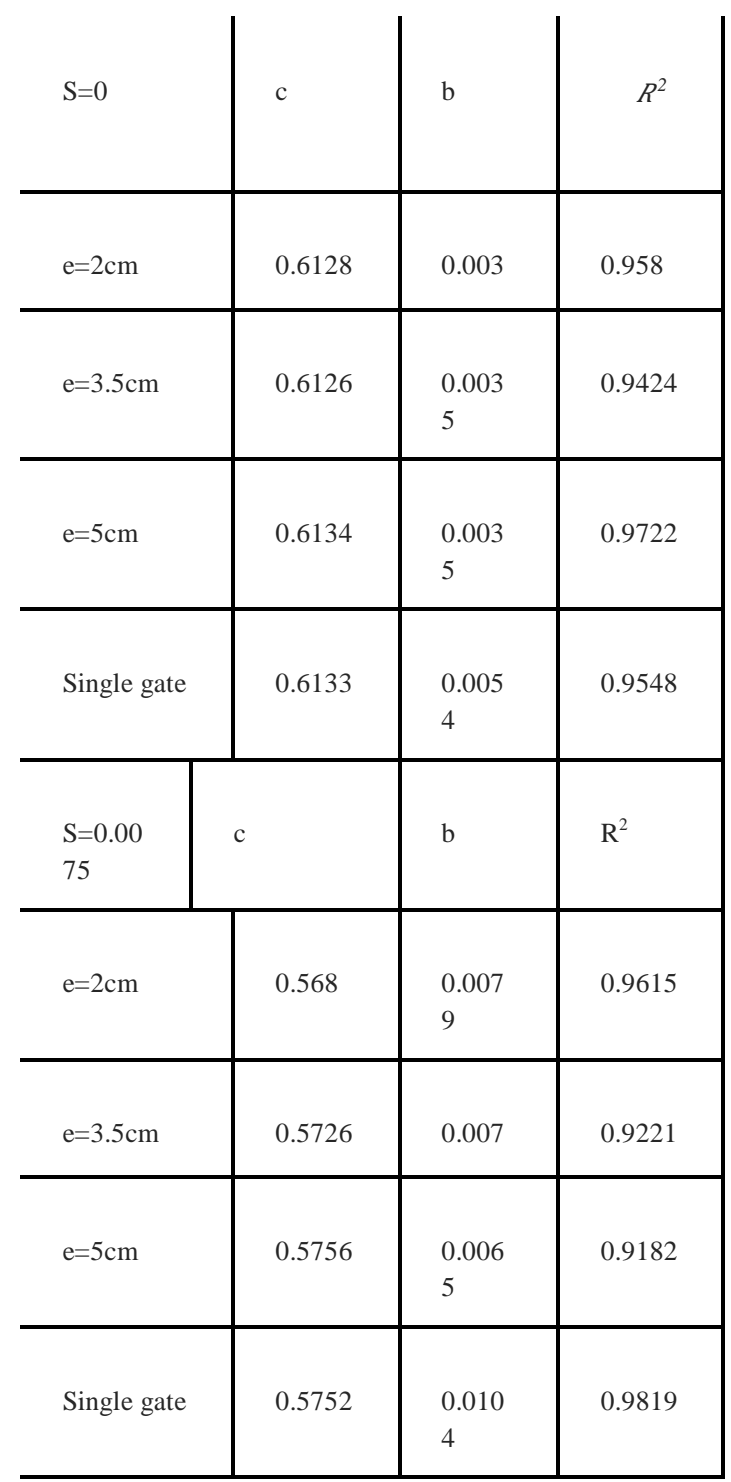

Figures $(11 \& 12)$ shows that the value of discharge coefficient $\mathrm{Cd}$ increases with the increase of $\frac{1}{\boldsymbol{F}^{2}}$, and its value increases with the increase distance between baffles. Comparing figure (11) with figure (12) it can be noted that the channel slope has a negative effect on the value of $\mathrm{Cd}$ which shows less values of discharge coefficient $\mathrm{Cd}$ for the same geometric combinations. 


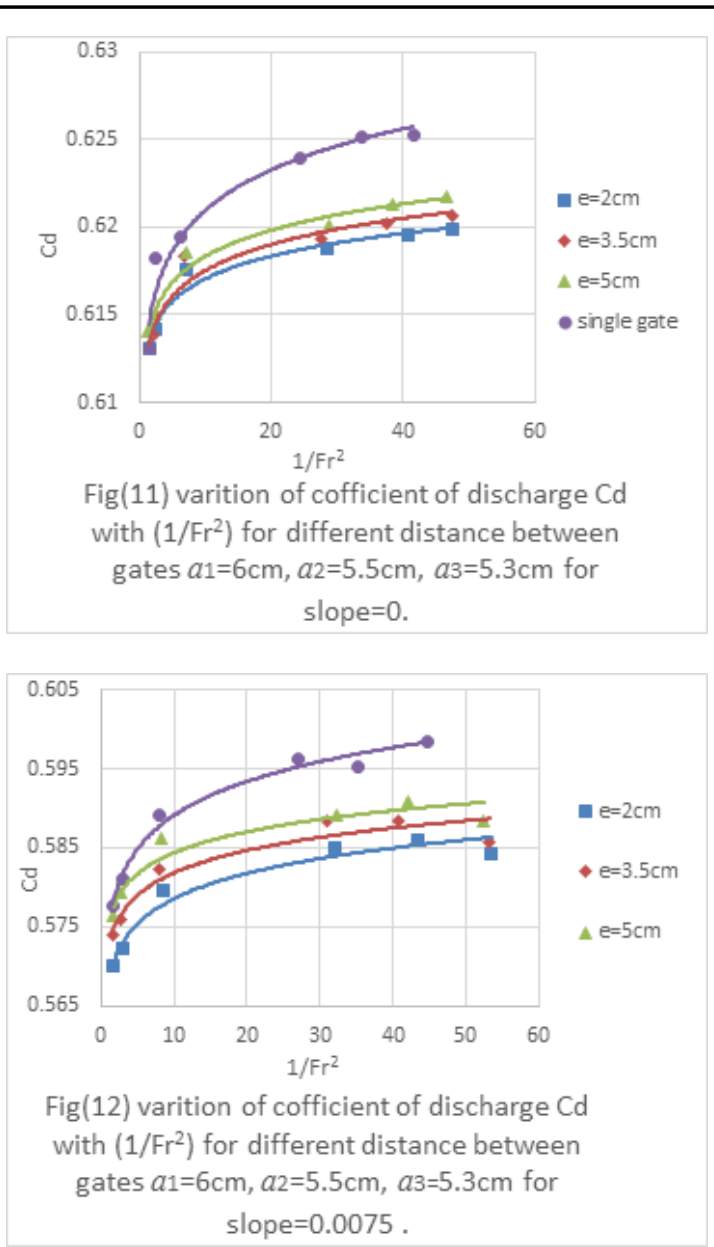

\subsection{Predicted Model}

Based on the dimensional analysis a relation between $\mathrm{Cd}$ and the parameters $(\mathrm{a} / \mathrm{H} 1$, $\mathrm{Cc}, \mathrm{e} / \mathrm{H} 1,1 / \mathrm{H} 1, \mathrm{~B} / \mathrm{H} 1$ and $1 / \mathrm{Fr}^{2}$ ) are predicted using (spss statistics) is presented in eq. (12).

$C d=0.58 *\left(\frac{a}{H_{1}}\right)^{-0.58} *(C C)^{-0.589} *\left(\frac{B}{H_{1}}\right)^{-0.66} *$ $\left(\frac{1}{\operatorname{Fr}^{2}}\right)^{-0.32} \cos \quad(\Phi) \ldots 12$

With correlation coefficient $\mathrm{R}^{2}=0.833$.

The relation between Cd observed experimentally and those predicted by equation (12) are plotted in fig (13) which give a good agreement between predicated and calculated values of $\mathrm{Cd}$.

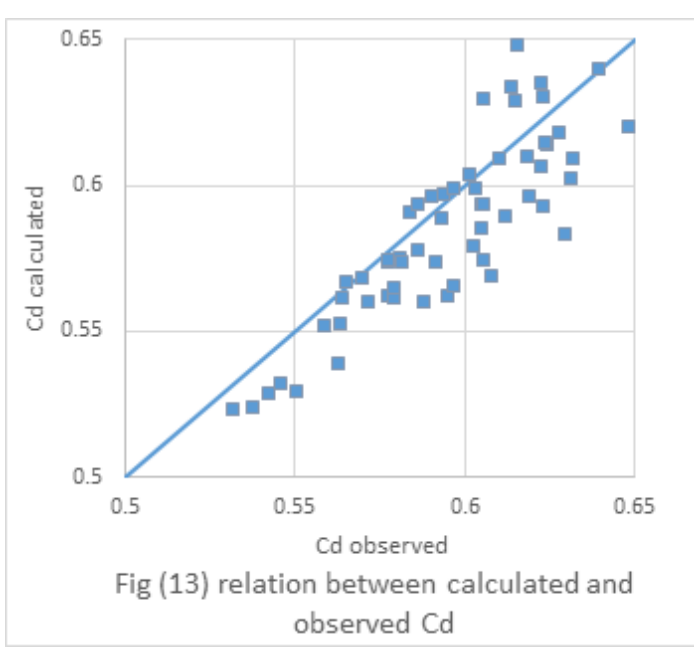

\section{CONCLUSION}

Based on experimental results of this study for flow through the three baffle sluice gates the following can be concluded:

a-The coefficient of discharge (Cd) decrease when the slop increase for all gate opening. b-The coefficient of discharge $(\mathrm{Cd})$ decrease as $\mathrm{B} / \mathrm{H}_{1}, \mathrm{e} / \mathrm{H}_{1}, \mathrm{a} / \mathrm{H}_{1}, \mathrm{l} / \mathrm{H}_{1}$ increase.

c-The coefficient of discharge $(\mathrm{Cd})$ increase as $1 / \mathrm{Fr}^{2}$ increase.

d- For a constant discharge the head of water upstream baffle sluice gate is more than that in front of single gate.ie the baffle sluice gates increase the head of water more than single gate.

\section{list of notation:}

$Q_{d}$ :discharge through the opening below the active gate $\left(L^{3} T^{-1}\right)$.

$Q_{u}$ : discharge over the active gate when the elevation of water increase above the top edge of active gate $\left(L^{3} T^{-1}\right)$.

\section{$Q_{\text {act }}:$ the total actual discharge through the standard rectangular weir $\left(L^{3} T^{-1}\right)$.}

Cd: the coefficient of discharge for the baffle sluice gate.

$g$ :acceleration due to gravity $\left(L T^{-2}\right)$.

$B$ : the width of the channel $(L)$.

$a$ :gate opening $(L)$. 
$a_{1}$ :the first gate opening.

$a_{2}:$ the second gate opening.

$a_{3}$ :the third gate opening.

$h$ :the head over top edge of active gate $(L)$.

$H_{1}:$ the total head(m); $H_{1}=a+L+h$

$\mathrm{H}_{2}$ : the head of water before first gate $(L)$.

$H_{3}$ : the head of water before second gate $(L)$.

$H_{4}$ : the head of water before third gate $(L)$.

$e$ : the distance between gates $(L)$.

$L:$ is the length of the active gate $(L)$.

$\mathrm{S}$ : the slop of channel.

$\rho:$ densityof water $\left(\mathrm{ML}^{-3}\right)$.

$\mu$ : dynamic viscosity $\left(\mathrm{ML}^{-1} \mathrm{~T}^{-1}\right)$.

\section{REFERENCES}

[1]Ansar, M., \& Ferro, V. (2001)." Simultaneous Flow over and under a Gate", Journal of Irrigation and Drainage Engineering, Vol 127, No.5, p 325-328.

[2] Babu, B. M., Mishra, P. K., \&Satyanarayana, T. (1996). "Performance of baffle-sluice modules with changed module dimensions", Journal of irrigation and drainage engineering, Vol. 122, No.5, p 310-313.

[3]Bijankhan, M., Mehrzad, M., Golzar, M., \&Kouchakzadeh, S. (2017). "Volumetric Water Delivery Using Baffle Sluice Modules: New Approach", Journal of Irrigation and Drainage Engineering,Vol. 143,No.10, 04017043.

[4]British Standard Institution (BSI) (1965). "ThinPlate Weirs and Venturi flumes in methods of measurement of Liquid Flow in Open Channel.", Part 4 A, BSI, 3681 BSI , London.

[5]Ferro, V. (2000). "Simultaneous flow over and under a gate", Journal of Irrigation and Drainage Engineering, Vol. 126, No.3, p190-193.

[6]Henry, H. R. (1950). "Discussion of Diffusion of submerged jets". Transaction. In ASCE, Vol. 115, p 687-694.

[7]Lin, C. H., Yen, J. F., \& Tsai, C. T. (2002)." Influence of sluice gate contraction coefficient on distinguishing condition", Journal of Irrigation and Drainage Engineering, Vol. 128, No.4, p 249-252.

[8]Mishra, P. K., Larsen, P., \&Satyanarayana, T. (1990). "Development of low-discharge bafflesluice modules", Journal of irrigation and drainage engineering, Vol .116,No.3, p444-453.

[9]Mohammed, A. Y., \& Khaleel, M. S. (2013). "Gate Lip Hydraulics under Sluice Gate", Modern Instrumentation, Vol.2, No. 1, 16.

[10]Negm, A., Al-Brahim, A., \& Alhamid, A. (2002)." Combined-free flow over weirs and below gates", Journal of Hydraulic research,ASCE, Vol. 40,No.3, $\mathrm{pp}(359-365)$.

[11]Rajaratnam, N. (1977). "Free flow immediately below sluice gates", Journal of the Hydraulics Division, Vol.103, No.4, p 345-351.
[12]Swamee, P. K. (1992). "Sluice-gate discharge equations". Journal of Irrigation and Drainage Engineering, Vol. 118, No.1, p 56-60. 


\section{دراسة مختبرية لتقدير معامل التصريف لثلاث بوابات كسح متتالية}

أن الهدف الرئيسي من هذه الدر اسة هو تقلقير معامل التصريف لثنلاث بو ابات كسح مثتالية ومقارنتها مع بو ابة مفردة. عندما يتغير ميل القناة

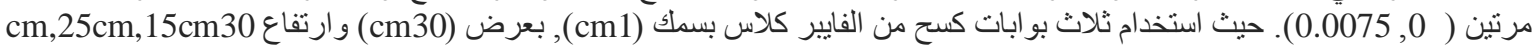

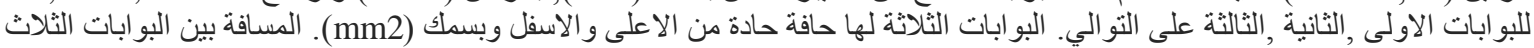

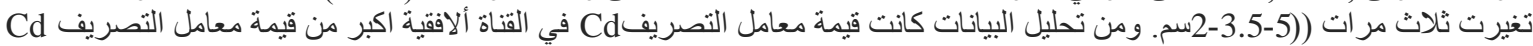

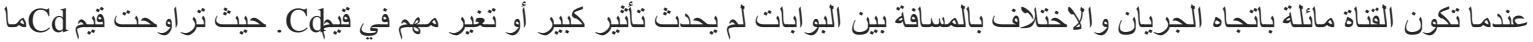

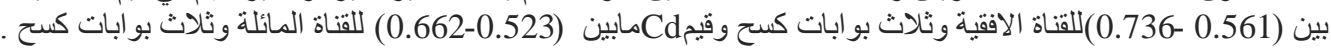

